\title{
GEOPOETRY: GREENWICH PENINSULA
}

Abstract

This text, with the accompanying images projected, was performed at the conference on 'The Mediated City' held at Ravensbourne College of Design and Communication, Greenwich Peninsula, between 1-3 April, 2014. The performance was given on Wednesday, the 2nd of April. The following day, Thursday the 3rd of April, the Geopoetry Reading it introduced was conducted around Greenwich Peninsula. The main contents of this reading can be found in The Sorcerer's Apprentice, no. 68-69 (March-April, 2014).

The two speakers (designated by the letters G. \& S.) sit on chairs at either end of a table, looking out at the audience. Between them, on the table, is a megaphone, with which each speaker announces the Set, the Game, the Ruling, and the Score. These announcements are marked in bold text.

\section{G. Prologue: Greenwich Meridian}

S.

\author{
Down a wandering path \\ I have travelled, \\ Where the setting sun \\ Lies upon the ground, \\ The tracks are hard and dry \\ Smoothened with \\ The weather's wear, \\ My mind did move \\ With them that had \\ Before me been, \\ Trodding down the ground \\ A track for me to follow, \\ Leaving marks for others \\ A sign for them to follow.
}

G. - David Dudgeon, Tracks (1999), from a cast-iron milepost that stands where the Thames Path crosses the Greenwich Meridian, above which is written:

G.

\author{
This is one of 1000 \\ mileposts funded by \\ The Royal Bank of \\ Scotland to mark the \\ Millennium and the \\ creation of the National \\ Cycle Network.
}




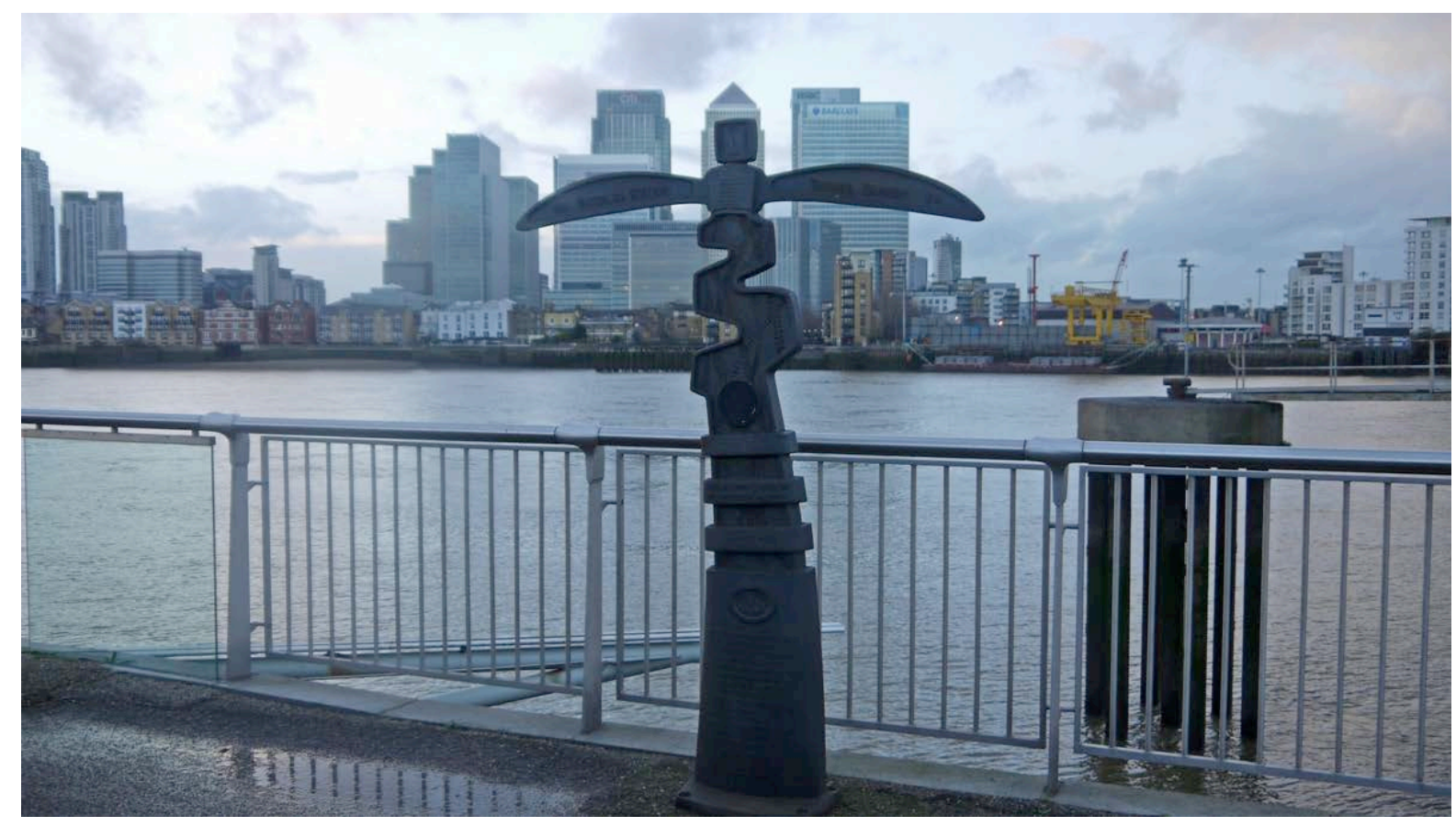

Figure 1. Greenwich Meridian, Thames Path. 


\section{S. FIRST SET: GEOPOETRY THEORY}

\section{S. Game 1: Traffic Island}

S. So, shall we start?

G. Is that a question?

S. Doesn't it sound like one?

G. Aren't you sure?

S. Aren't you?

G. Is repetition allowed?

S. Allowed by whom?

G. Why are you asking me?

S. Whom else should I ask?

G. Am I qualified to answer?

S. Are you qualified to ask?

G. Ask about what?

S. Shall we find out?

G. How do we start?

S. Haven't we already?

G. Okay, what is geopoetry?

S. Geopoetry / d3Iə:(U)'pəUItri / noun. E21. [f. geo(graphy) + poetry.]

Poetics. A theory and practice that locates poetry in the place and performance of the text. For the geopoet, the text is only the score for the performance, the performance the precipitate of the event, and the event a collective realisation specific to the time, place and makers of its happening. The point of a geopoetry reading is not to use sites as background, illustration, context or stage to the texts, but to use the texts to articulate these places, the passage between them, and the journey they compose. This journey, from one place to the other, is as much a component of a geopoetry reading as the texts themselves. The footsteps of the geopoetry walker are like syllables in the words of the poem, articulating - like the click of the tongue / in the mouth of the speaker - the space of the city they cover. The poetry of the reading is not in the text but in the act of reading itself. We want to do to space what poetry does to words.

\section{G. Statement: 1-/ove.}




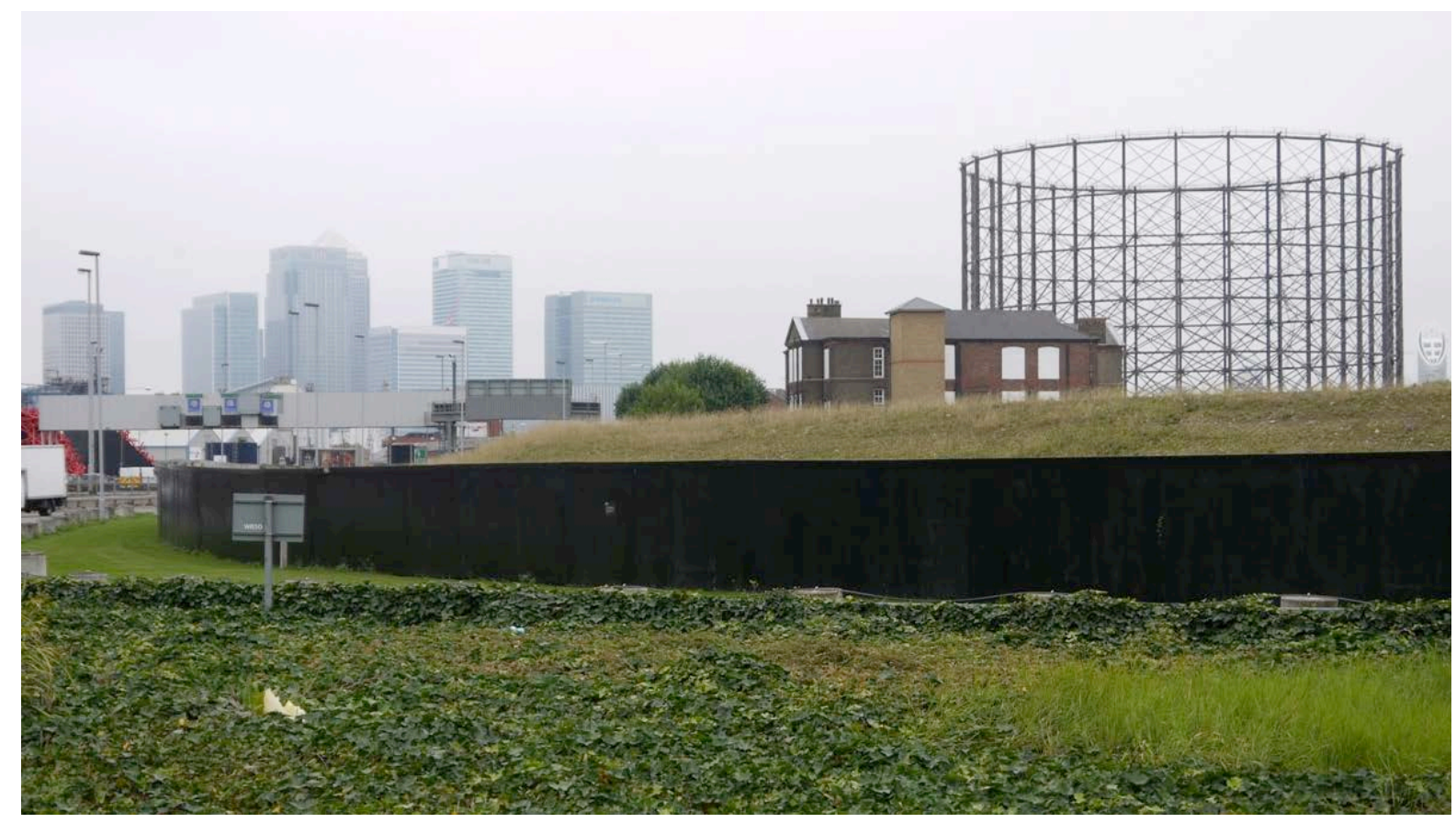

Figure 2. Traffic island, Blackwall Lane. 


\section{Game 2: The River Gardens}

G. How can you 'do to space what poetry does to words'?

S. What does poetry do to words?

G. What does poetry do to space?

S. Is that a non sequitur?

G. Aren't they allowed?

S. Does that count as a question?

G. Did you ask one?

S. About poetry?

G. Is that what we're talking about?

S. Wasn't it about space?

G. What kind of space?

S. How many kinds are there?

G. What kind are we in now?

S. Is it real or virtual?

G. Are we producing or consuming?

S. At work or at play?

G. In public or private?

S. Doesn't it depend on the place?

G. Don't you mean space?

S. Is there a difference?

G. The distinction between space and place describes something particular to the contemporary city. Space is always and everywhere the same, without inherent qualities or qualitative distinctions. Space is a commodity, with dimensions that can be measured, valued and exchanged. This has transformed our relationship to the city into one that is quantifiable, like the cost of office space per square foot. Place, by contrast, is specific and relational, with a social history and qualities produced and reproduced by the collective actions of its inhabitants. Place always has a temporal dimension within which we engage with the physical city, generating a sense of place. If space is an east-bound train on the Jubilee Line, and the time is 8.44am on Wednesday, the 2nd of April, 2014, then the place is North Greenwich tube station. Space is to place what language is to the spoken word: the abstract legislator of its concrete articulations.

\section{S. Statement: 1-all.}




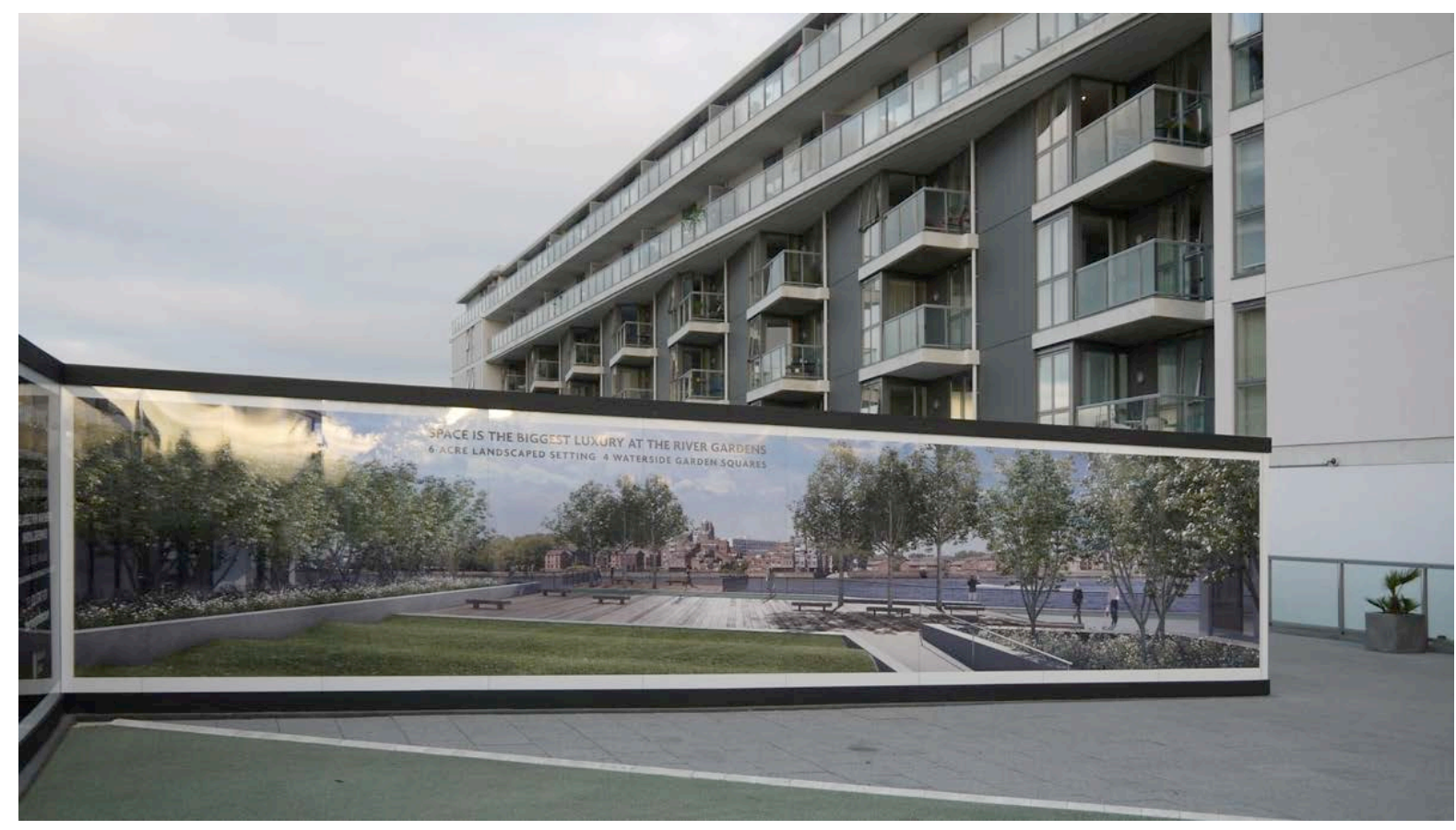

Figure 3. Billboard, The River Gardens. 


\section{Game 3: Piper's Wharf}

S. What are 'concrete articulations'?

G. Don't you know what concrete is?

S. Can words be concrete?

G. Can they be abstract?

S. When are they not?

G. When they're concrete?

S. Aren't they always?

G. Does that mean yes?

S. Is that what you think?

G. Are you avoiding the question?

S. What question was that?

G. Are words abstract or concrete?

S. What would you say?

G. What do I think?

S. Is that what I said?

G. Is that your answer?

S. Does it sound like one?

G. Are we playing a game?

S. Don't you know the rules?

G. The rules of what?

S. Haven't you been listening?

G. Have you been speaking?

S. Am I not speaking now?

G. Do you have something to say?

S. As the urban environment is increasingly privatised, the space of the city has become increasingly prescribed, with the main, if not exclusive, purpose of making and spending money. The majority of city-dwellers live out their lives along a well-inscribed triangle between home, work and the repeatedly revisited sites of consumption, the distinctions between which have become increasingly blurred. But though the function of urban space is largely dictated by its design, the relationship between space and use is not as fixed as the architect, property-developer, land-owner or state would have us believe. We are still able - briefly and increasingly illegally - to appropriate these spaces, to 'misuse' them, and, for a moment, transgress their interdictions, opening the place they legislate to other readings. Geopoetry is one way of doing this.

\section{G. Statement: 2-1.}




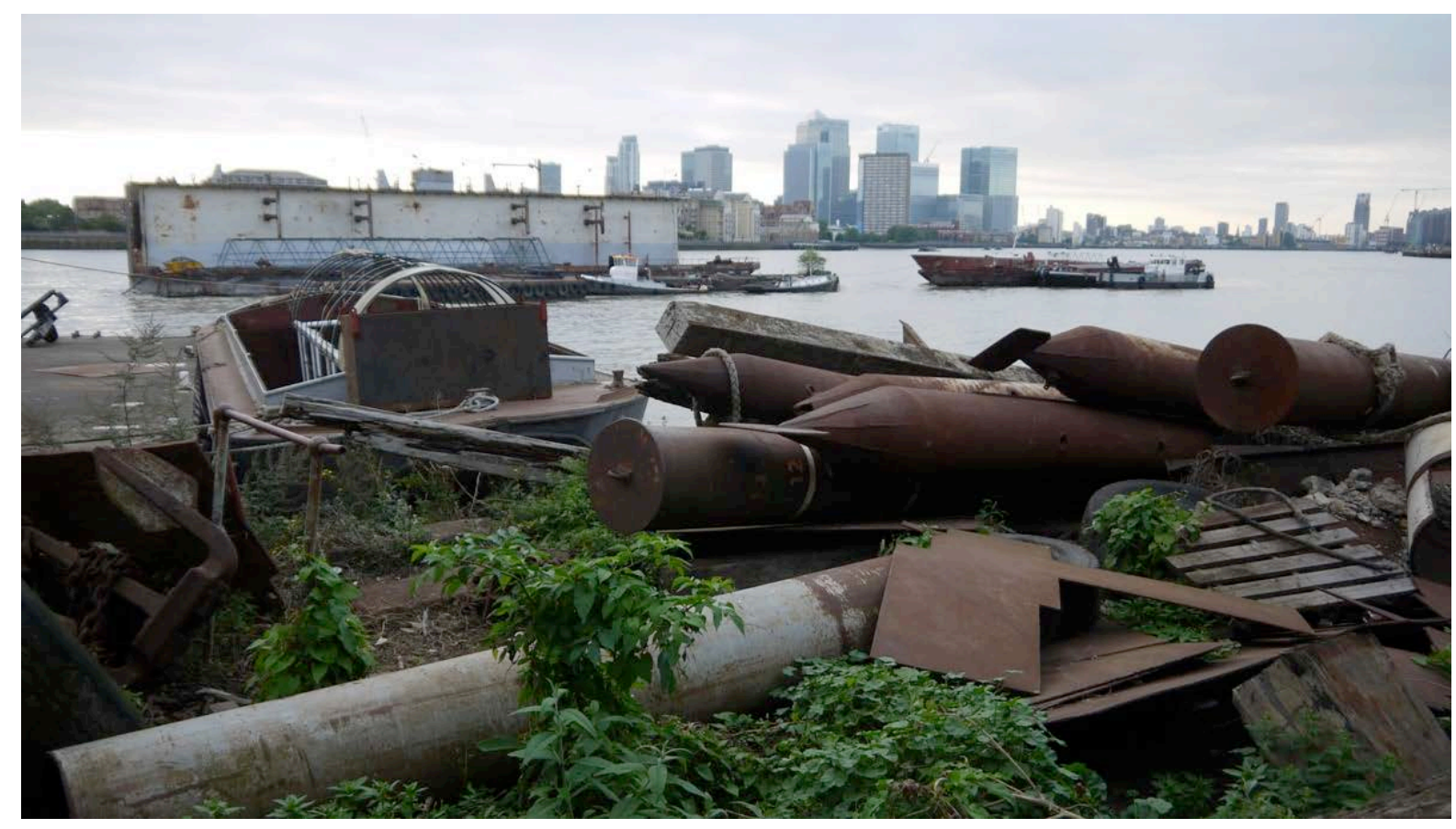

Figure 4. Piper's Wharf. 


\section{Game 4: Central Park}

G. Are you talking about trespassing?

S. Trespassing on what?

G. Is that what you mean by transgression?

S. Does transgression have a meaning?

G. Can meaning be transgressive?

S. On what would it trespass?

G. Is that what transgression means?

S. Isn't it like walking?

G. But can't you walk anywhere?

S. Have you tried to?

G. Where can't you walk?

S. Where can you?

G. But what does that have to do with reading?

S. Can you read anywhere?

G. Can you read anything?

S. What can't you read?

G. Where can't you read?

S. Are there no rules to speak of?

G. Are there any rules to speaking?

S. What are the rules of walking?

G. PARK RULES. We want everyone to enjoy this park, so please, NO:

- Fires or BBQs

- Organised ball games or studded footwear

- Unauthorised vehicles

- Flytipping

- Unauthorised events or sports.

Dog owners, please:

- Keep your dog on a lead

- Clean up after your dog

- Keep your dog under control.

Anyone who breaks these rules will be asked to leave the park immediately and irresponsible dog owners will be fined. Dog wardens operate in this park.

This park is private land owned by Greater London Authority Land and Property Limited, part of the Mayor of London.

\section{S. Statement: 2-all. Set point.}




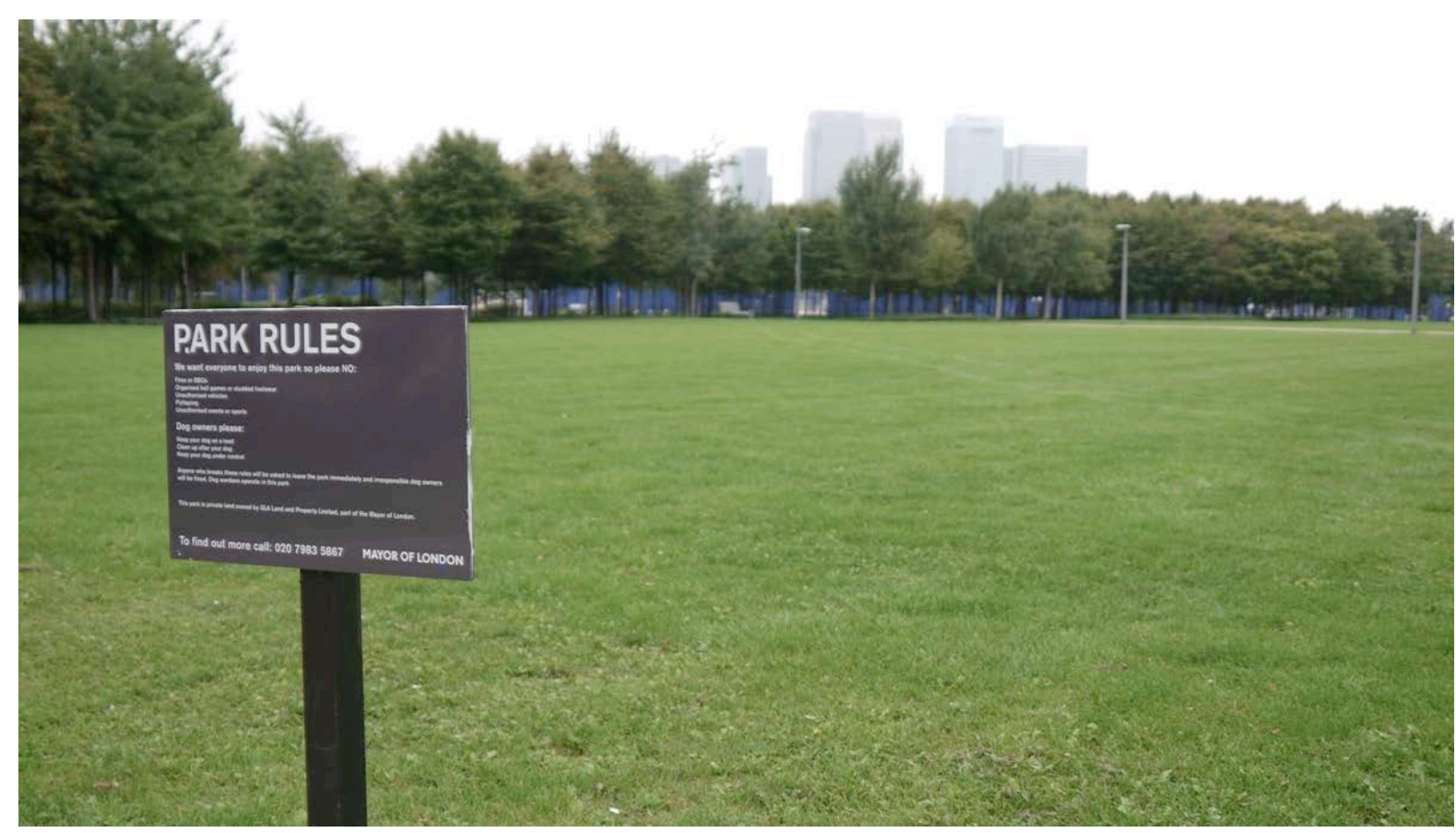

Figure 5. Notice board, Central Park. 


\section{Game 5: Mitre Passage}

S. Is this some kind of play?

G. Why, have you forgotten your lines?

S. Or is it a cultural critique?

G. Which culture did you have in mind?

S. Or a sociological study?

G. A study of what?

S. What's it about then?

G. Didn't you read the title?

S. But why Greenwich Peninsula?

G. Have you seen it lately?

S. The place or the plans?

G. What's the difference?

S. Is there a difference?

G. Between the buildings and the pictures?

S. Have you ever seen somewhere with so many images of itself?

G. What are they depicting?

S. Whom are they describing?

G. How would you describe them?

S. What language would you use?

G. In what language are they written?

S. The city is a discourse, and this discourse is an actual language: the city speaks to its inhabitants, and we speak our city, the city in which we live, simply by inhabiting it, by wandering through it, by looking at it. Yet the problem is to extract an expression like 'the language of the city' from the purely metaphorical stage. If we want to undertake a semiology of the city, the best approach will entail a certain ingenuity on the part of the reader. It will require many of us to attempt to decipher the city where we are, starting, if necessary, with a personal report. Gathering all these readings by various categories of readers, we would thereby elaborate the language of the city. This is why I would say that the most important thing is not so much to multiply surveys or functional studies of the city, as to multiply the readings of the city, of which, so far, only the poets have given us some examples. For the city is a poem.

- Roland Barthes, 'Semiology and Urbanism', 1967.

\section{G. Statement: 3-2. Game and First Set.}




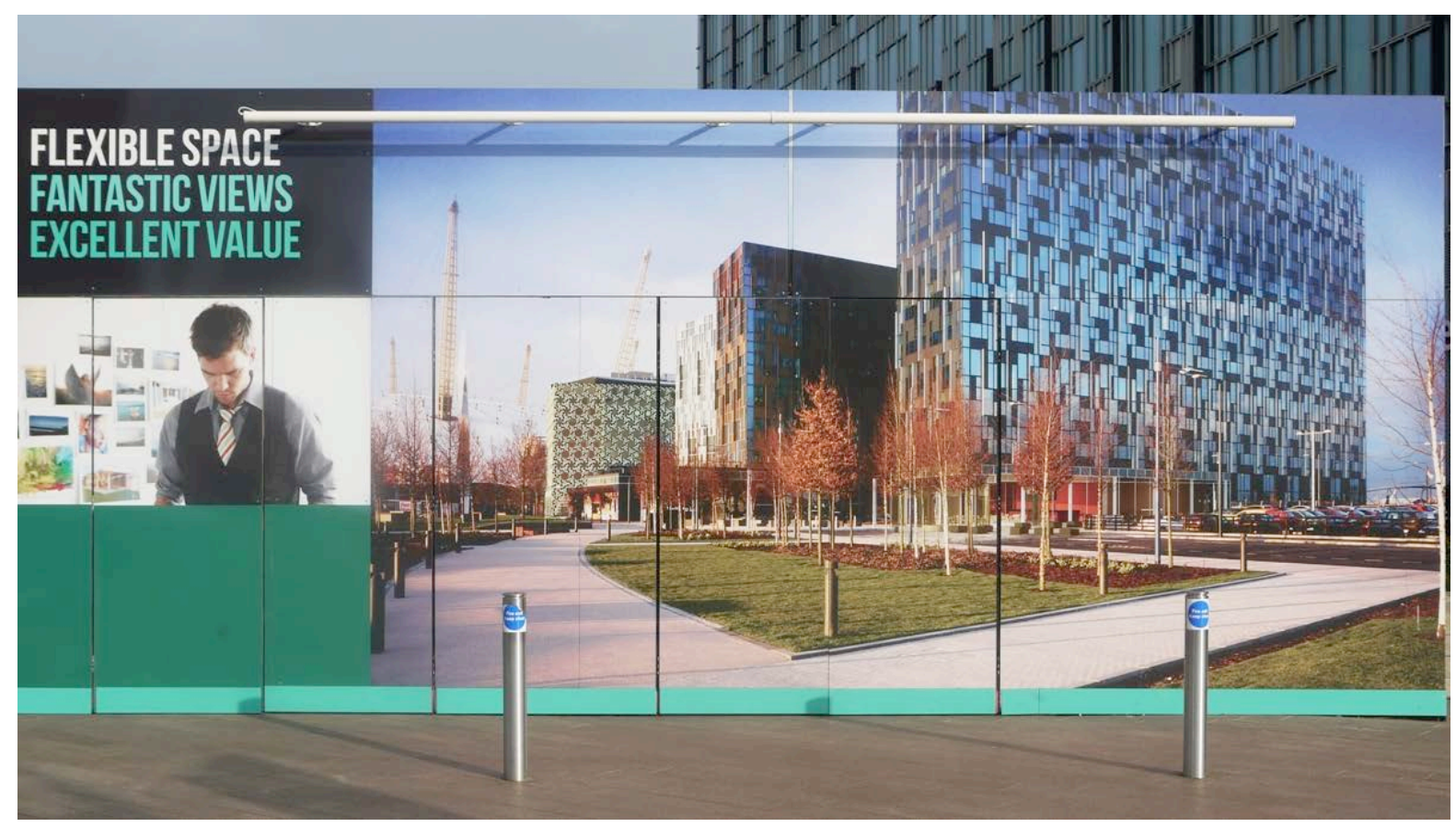

Figure 6. Billboard, Mitre Passage. 


\section{SECOND SET: READING GREENWICH PENINSULA}

\section{Game 1: Ravensbourne College}

G. So, where are we?

S. Don't you know?

G. But what are we doing here?

S. Where else should we be?

G. Isn't this an institution of higher learning?

S. Higher what?

G. But what's it doing here?

S. Why shouldn't it be here?

G. In an entertainment district?

S. Isn't it a shopping centre?

G. Was it always here?

S. What are you getting at?

G. Don't you think it's an odd location?

S. Should I?

G. Shouldn't you?

S. How many students come here?

G. How often do they come here?

S. How much do they spend here?

G. What do they buy here?

S. Whom do we have to thank for being here?

G. We want to make sure our students have the skills and ability to succeed in the creative industries of the future. Design and communication industries will continue to be transformed by technology. It makes sense for us to put Apple at the centre of our learning strategy, because Apple's technology is so significant in that transformation. Apple is designed for innovative teaching and learning, and suits our pedagogical approach really well. It also supports the image of international excellence we want for the college as we move to an amazing new building in Greenwich. The design of that facility from shared spaces for collaboration to fabulous digital studios and suites - reflects the future creative environment in which Apple has such a big stake. The move will open up great new learning and commercial opportunities as we move past the London Olympics, and Apple is key to achieving our goals. What could be better practice for the working world of tomorrow?

- Professor Robin Baker, Director and Chief Executive of Ravensbourne College, Apple in Education Profiles, 2014.

\section{S. Statement: 1-/ove.}




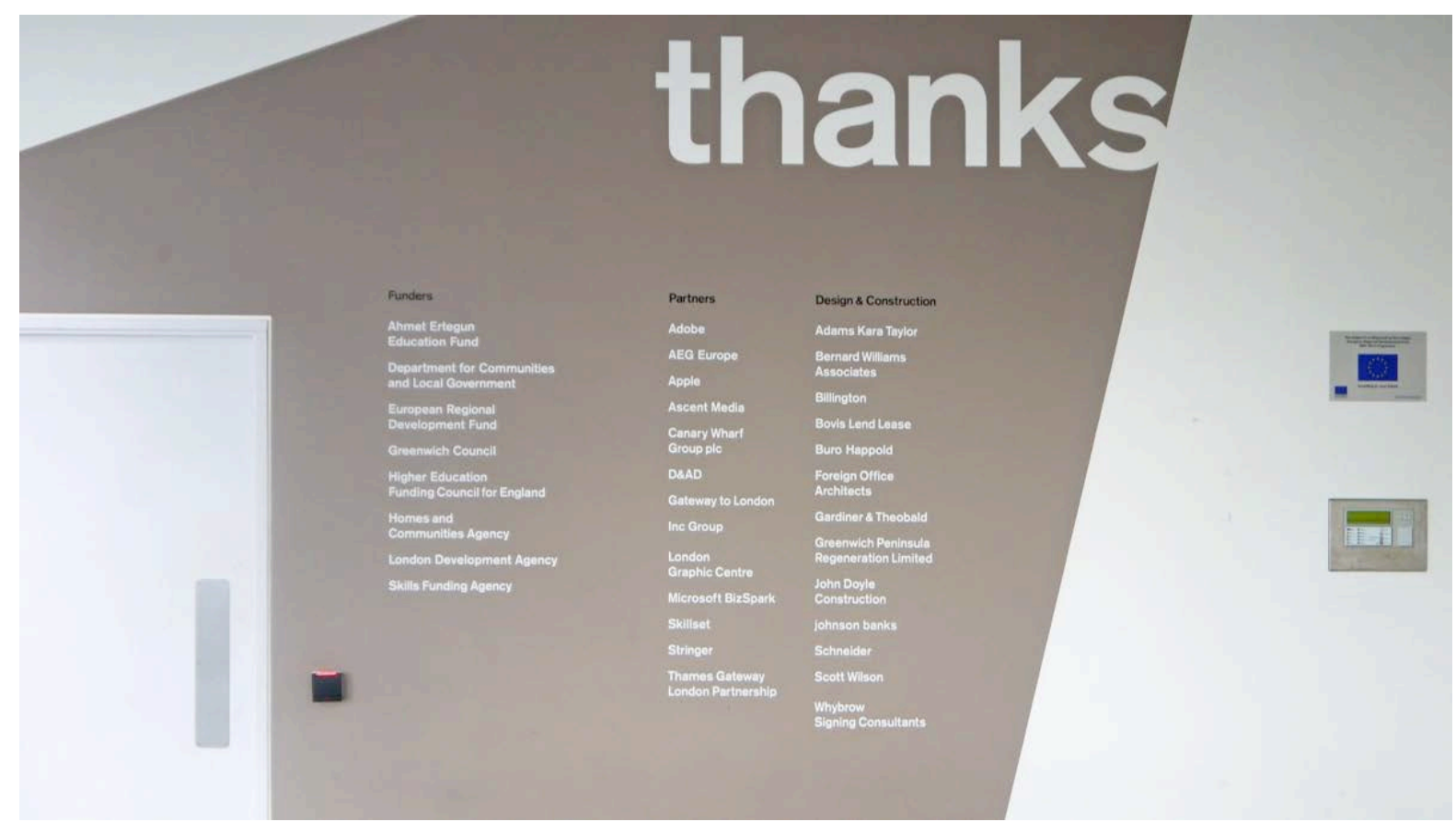

Figure 7. Foyer, Ravensbourne College. 


\section{Game 2: The 02 Arena}

S. What is the $\mathrm{O} 2$ Arena?

G. You mean the Millennium Dome?

S. How much did it cost?

G. In today's money?

S. Does a billion pounds sound too much?

G. Who paid for that?

S. Whom do you think?

G. Wasn't it the National Lottery?

S. Doesn't that mean us?

G. And who owns it now?

S. Didn't they sell it to the Anschutz Entertainment Group?

G. Aren't they a U.S. corporation?

S. Does that surprise you?

G. How much did they pay?

S. Would you believe $£ 1$ ?

G. Is that what they mean by public-private investment?

S. Why else would business get involved?

G. Is that a rhetorical question?

S. However much architectural projects have a seeming objectivity, however much the producers of space may, occasionally, have the best intentions in the world, the fact is that volumes are invariably dealt with in a way that refers the space in question back to the land, to a land that is still privately (and privatively) owned. Built-up space is thus emancipated from the land in appearance only. At the same time, it is treated as an empty abstraction, at once geometric and visual in character. This relationship is both a practice and an ideology: an ideology whose practitioners are unaware that their activity is of an ideological nature, even though their every gesture makes this fact concrete. The supposed solutions of the planners thus impose the constraints of exchangeability on everyday life, while presenting them as both natural, normal and technical requirements - and often also as moral necessities, responding to the requirements of public morality. Here, as ever, the economic sphere has common cause with the moral order.

- Henri Lefebvre, The Production of Space, 1974.

\section{G. Statement: 1-all.}




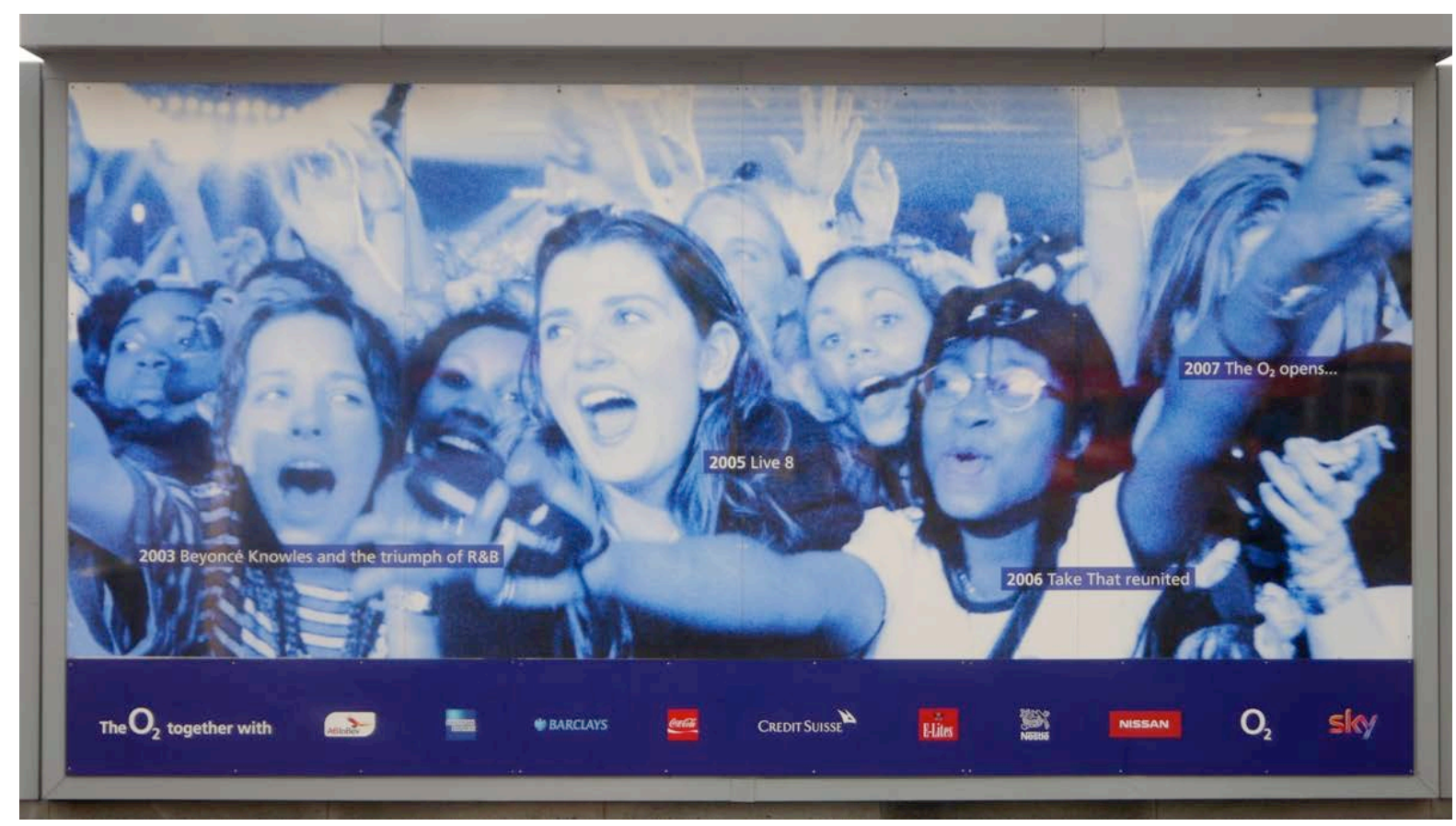

Figure 8. Billboard, O2 Arena. 


\section{Game 3: Greenwich Peninsula}

G. Who else comes here?

S. Aren't there local residents?

G. Why do you say that?

S. Didn't you see the signs?

G. What signs?

S. Something about affordable housing?

G. What do they mean by 'affordable'?

S. Does that mean the rest is unaffordable?

G. Have you seen how much they cost?

S. How many are affordable?

G. Wasn't it $35 \%$ ?

S. What do you mean 'was'?

G. Didn't you hear the news?

S. About the new agreement?

G. So how much of the new housing will be affordable?

S. How much do you think?

G. Is that what they mean by 'a new sustainable community'?

S. Sustainable for whom?

G. What brought this about?

S. Isn't it something to do with the takeover?

G. Have you heard of Knight Dragon?

S. Aren't they a Hong Kong corporation?

G. Haven't we been here before?

S. But what difference will it make?

G. One of the key drivers for the current proposal is to utilise approximately $£ 50$ million of the affordable housing grant that is currently allocated for use on the Greenwich Peninsula master plan. The original condition for the grant allocation was that the affordable housing would be built by 2015 . As part of the current proposal, agreement has been reached with the Greater London Authority to extend the deadline in respect of 380 of the 646 affordable homes to 31st December, 2017.

The percentage of affordable housing that is to be secured across the 11 plots is approximately $21 \%$. Normally, where such levels of affordable housing grant are provided on a site, the Council would expect to secure in the order of $35 \%$ affordable housing. However, the Greenwich Peninsula site is subject to certain unique and exceptional circumstances that mitigate against such an outcome. These principally relate to the cost to the Government of remediating the site and providing the new infrastructure such as roads, parkland, riverside walk and river wall improvements between 1997 and 2004, and the terms under which the Government then sold the Greenwich Peninsula land to Greenwich Peninsula Regeneration Limited for redevelopment.

- Minutes of the meeting of the Royal Borough of Greenwich Planning Board on the Proposal to modify the Deed of Planning Obligation in respect of Development at Greenwich Peninsula, 28 February, 2013.

\section{S. Statement: 2-1.}




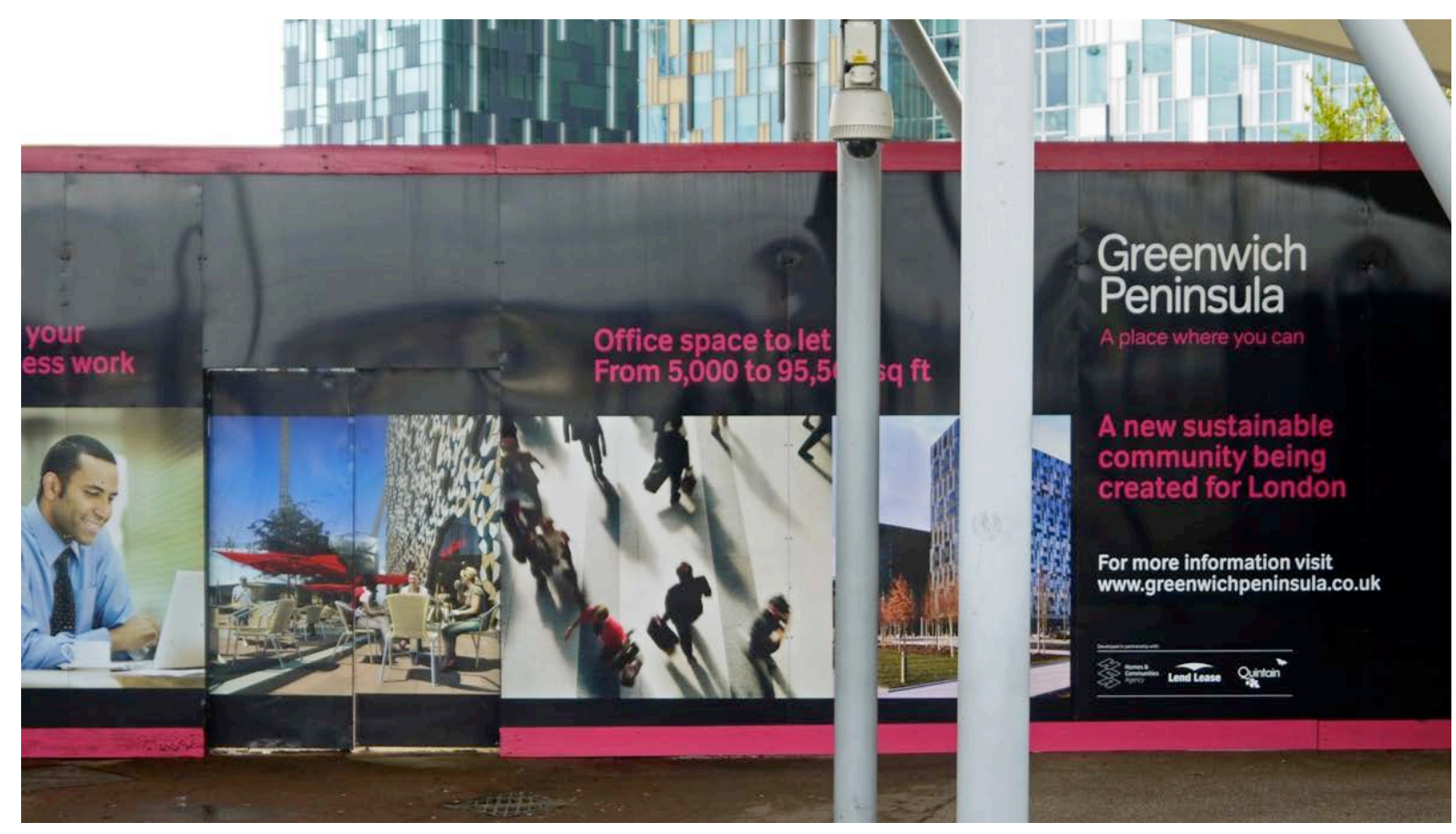

Figure 9. Billboard, North Greenwich Pier. 


\section{Game 4: Peninsula Square}

S. Could I ask you a question?

G. Isn't that a question already?

S. Are we on public land?

G. What does that mean?

S. Is it for public use?

G. What use did you have in mind?

S. Does the public own it?

G. Can the public own land?

S. Must property always be private?

G. Private from whom?

S. Can there be property without privation?

G. What do you think?

S. So who is being deprived?

G. Whom do you think?

S. Aren't you just playing on words?

G. Does this sound like a game?

S. Are you going to answer my question?

G. Does it really matter?

S. Peninsula Square is private property. Management reserve the right to refuse admission or to request any person to leave, where it is reasonable to do so. Anyone creating a nuisance or disturbance or behaving in an unreasonable manner will be required to leave.

No right of way, public or private, is acknowledged over Peninsula Square. Any use of this land is with the permission of the landowner. The ways on this land have not been dedicated as highways, bridleways or footpaths, nor is there any intention to so dedicate them.

\section{G. Statement: 2-2. Set point.}




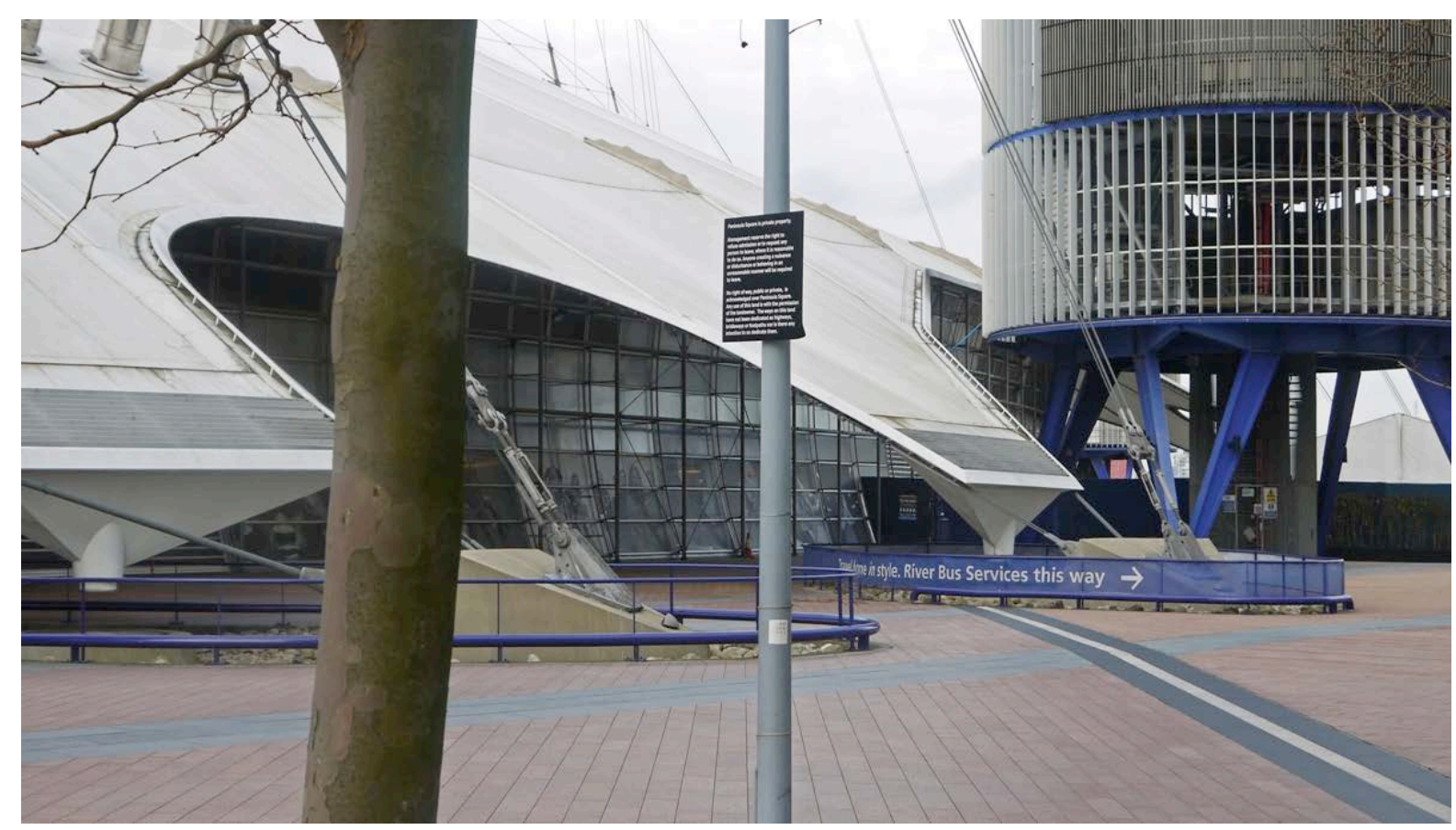

Figure 10. Notice board, Peninsula Square. 


\section{Game 5: Peninsula Quays}

G. Is this where we're heading?

S. An image of our future?

G. A beacon for 21st-century living?

S. The haves and the have-nots?

G. For richer for poorer?

S. In sickness or in wealth?

G. Gated communities?

S. Private security guards?

G. Ghettos for the super rich?

S. New slums for the newly poor?

G. Corporate ownership?

S. Ownership of what?

G. What have you got?

S. But does it matter, at the end of the day?

G. Does what matter at the end of the day?

S. Does it matter who owns London?

G. Dispersal Powers. These provisions establish a power to direct people away from an area where they are engaged in, or are likely to be engaged in, anti-social behaviour. This is a power for constables and Police Community Support Officers to issue a dispersal direction to any person aged 10 and over to leave a specific area and not return for up to 48 hours. The use of this power must be authorised by a police officer of at least the rank of inspector. Knowingly breaching the direction is a criminal offence. There is also a power to require property that has been used (or is likely to be used) in the anti-social behaviour to be surrendered.

The test that needs to be met is that the constable has reasonable grounds for suspecting that the person's behaviour in the area is contributing to anti-social behaviour (which is behaviour that causes harassment, alarm or distress) or crime or disorder in the area or is likely to contribute to anti-social behaviour or crime or disorder in the area; and that the direction is necessary for the purposes of reducing the likelihood of the occurrence of anti-social behaviour or crime or disorder in the area.

- Home Office, Memorandum on issues arising under the European Convention on Human Rights in relation to the Anti-Social Behaviour, Crime and Policing Bill, 18 October, 2013.

\section{S. Statement and legalese: 3-2, Game and Second Set.}




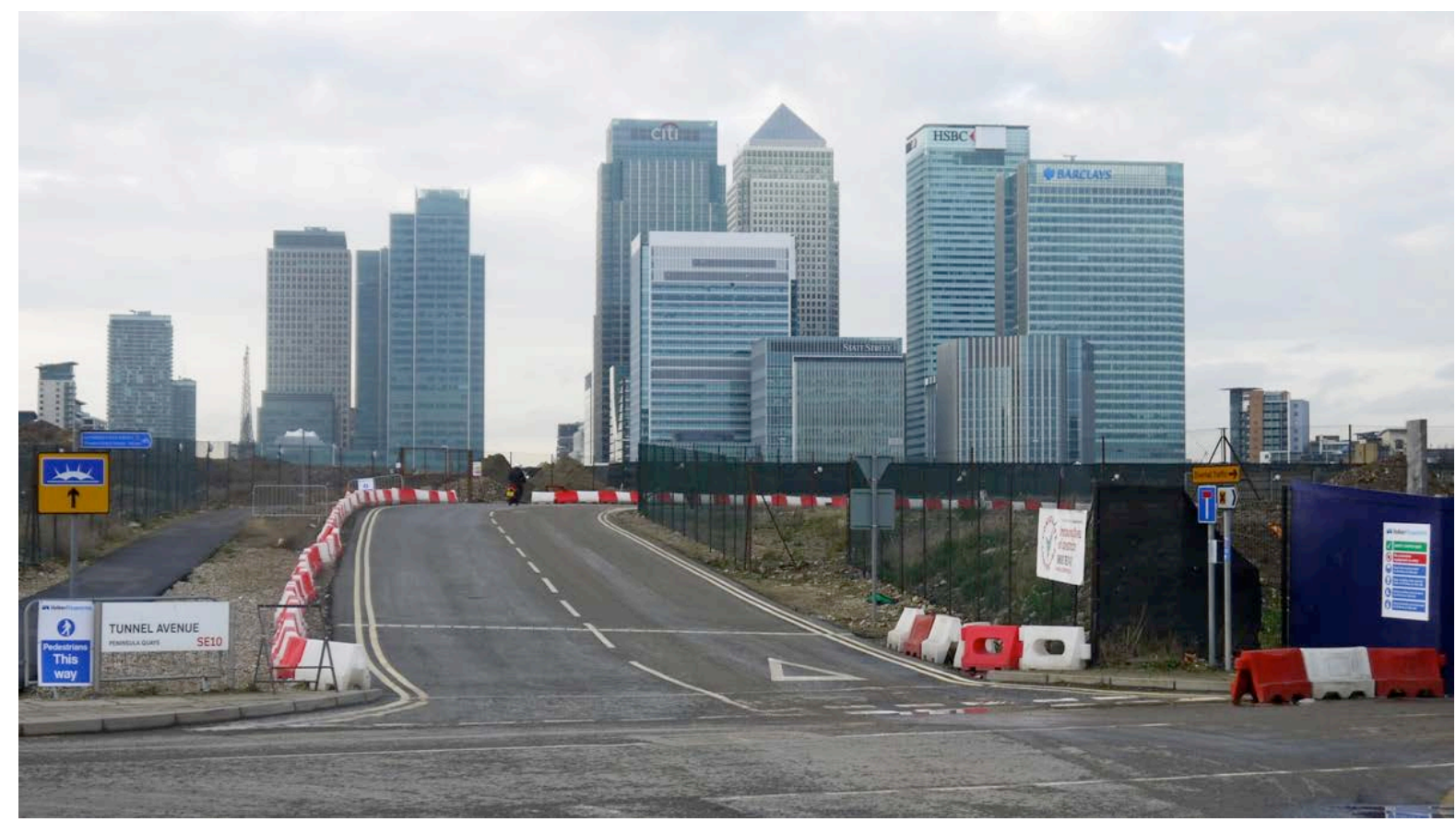

Figure 11. Tunnel Avenue, Peninsula Quays. 


\section{THIRD AND FINAL SET: GEOPOETRY PRACTICE}

\section{Game 1: Thames Path}

G. So, what do you do?

S. For a living, you mean?

G. What do you do to keep yourself busy?

S. What field am I in?

G. What path are you on?

S. What career am I currently pursuing?

G. What's your profession?

S. How am I employed?

G. What line of work did you say you are in?

S. What's my business?

G. What job do you do?

S. What do I do to make money?

G. How do you pay your way, these days?

S. What type of work is it that I do?

G. How do you manage to make ends meet?

S. What, precisely, do I do to get by?

G. How do you keep the wolf from the door?

S. What sort of thing do I do for a crust?

G. What's your game?

S. How do I live?

G. What are you doing, exactly, with your life?

S. You haven't understood me: I'm not talking about 'poems'. It is towards poetry that we are gravitating. There is no knowledge other than knowledge of the particular. There is no poetry other than the poetry of the concrete. It matters very little to me whether I am right or not. I do not seek to be right. I seek the concrete. That is why I speak. I do not acknowledge the right of anyone to question the premises of speech, or of expression. The concrete has no other form of expression than poetry. I do not acknowledge the right of anyone to question the premises of poetry. And I do not acknowledge criticism. It is not to criticism that I have devoted my days. My days belong to poetry. Make no mistake, sniggerers: I lead a poetic life. A poetic life - pray engrave that expression on your minds. I do not acknowledge the right of anyone to re-examine my words, or to quote them against me. They are not the terms of a peace treaty. Between you and me, it is war.

- Louis Aragon, ‘The Peasant's Dream', 1926

\section{G. Statement and rhetoric: 1-love.}




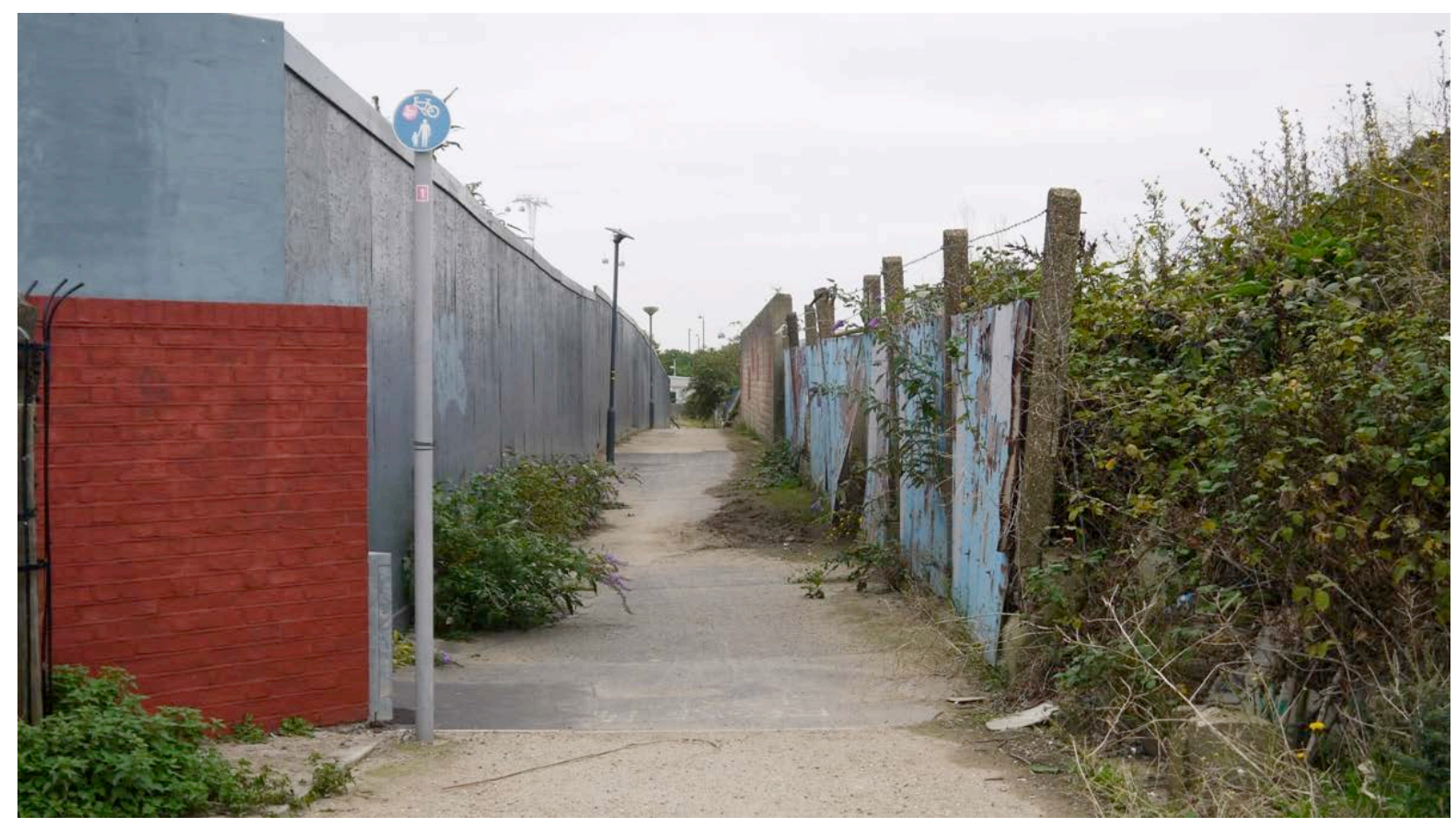

Figure 12. Thames Path. 


\section{Game 2: Ordnance Crescent}

S. Are you planning a demonstration?

G. Why do you say that?

S. Isn't that a megaphone?

G. Is that a problem?

S. Were you planning to use it?

G. Is that your business?

S. Do you want me to make it my business?

G. What is your business?

S. Where are you going?

G. Why do you ask?

S. Do you mind if I accompany you?

G. Who do you work for?

S. Why do you think I have to tell you?

G. Are you a cop?

S. Do I look like a cop?

G. Do you mind if I take your photo?

S. Do you want me to confiscate your camera?

G. Do you have the authority to do that?

S. Do you want to find out?

G. What is your authority?

S. What do you think?

G. Are you making this up?

S. Does it sound made up?

G. Or did this happen?

S. Why don't you find out?

G. Dressed in the black jacket, grey trousers, white shirt, black tie, shiny boots, peaked hat, dark sunglasses, ID card and other accoutrements of a security man, approach individual members of the public who stop in the apparently-public but in fact privately-owned Peninsula Square, and with an insistent sweep of your hand say to them in a tone of bored authority: 'I'm sorry Sir (or Madam), you'll have to move on.' Don't try to explain your actions, or respond to questions or confrontation. Whether the person obeys your instructions and moves on, or whether they challenge you as to why they must, who you are, or what authority you have, give them a handout printed with a text asking them about their awareness of the extent of private ownership of public space in London and the degree of control of its owners over our actions when on it.

\section{S. Statement: 1-1.}




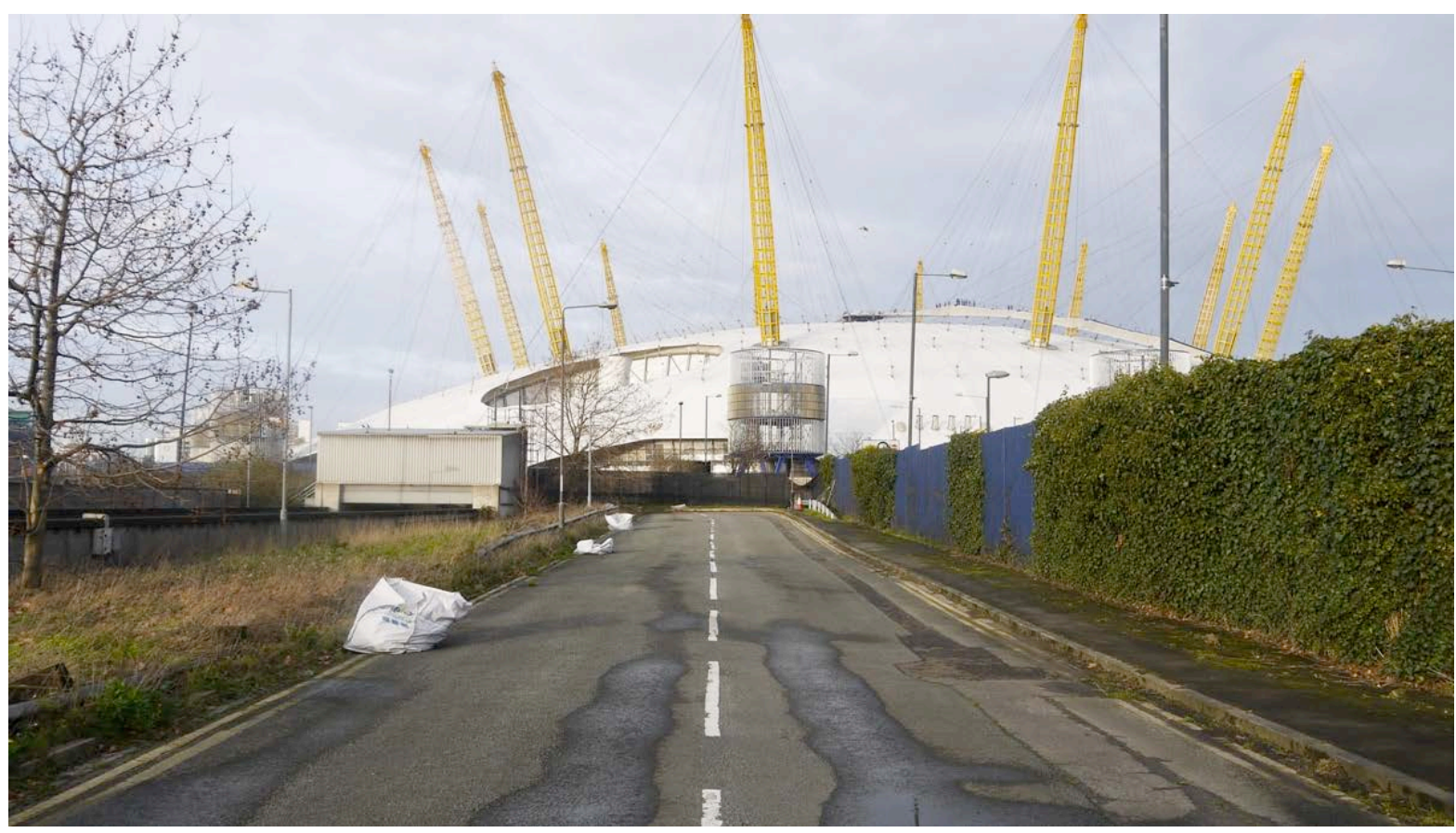

Figure 13. Ordnance Crescent. 


\section{Game 3: Morden Wharf}

G. But what's this got to do with poetry?

S. What do you mean poetry?

G. Why can't you just write a book?

S. Would you read what's in it?

G. Whom do you think will listen?

S. Whom do you listen to?

G. Why not write something poetic?

S. Is the poetic worth writing about?

G. Is this really the task of poetry?

S. What is the real task of poetry?

G. Aren't there venues set aside for poetry readings?

S. Why do you think they're set aside?

G. Aren't you inflicting yourself on the public?

S. Do you think I'm what's afflicting the public?

G. Can't you respect private property?

S. Do you mean the land that we walk on?

G. Aren't you just looking for trouble?

S. Do you think I have to go looking?

G. Are you ready for the consequences?

S. Aren't we already living with them?

G. But what, exactly, are you hoping to achieve?

S. Poetry performed is the dramatisation of the limits of speech and freedom, or it isn't poetry. All the rest is bed-side reading for judges of poetry prizes, the stock-in-trade of summer reading lists for beach holidays, or the destination of Christmas book-vouchers for relatives you never see. I piss on Poems on the Underground beside adverts for smart phones. I piss on poet laureates and their honourslist-courting subservience to the monarchy. I piss on poetry festivals funded by Lottery money in English country villages. I piss on open-mic poetry pub nights for paying amateurs. I piss on professional poets and the self-congratulating apparatus of tasteful publishing that supports them. I piss on poems read by politicians at the graveside of people they wish they had been. I piss on the poetry of sense and sensibility when the language we breathe is choking in the grip of corporate speech. Poetry performed is the dramatisation of the limits of speech and freedom, or it isn't poetry.

\section{G. Statement and Repetition: 2-1.}




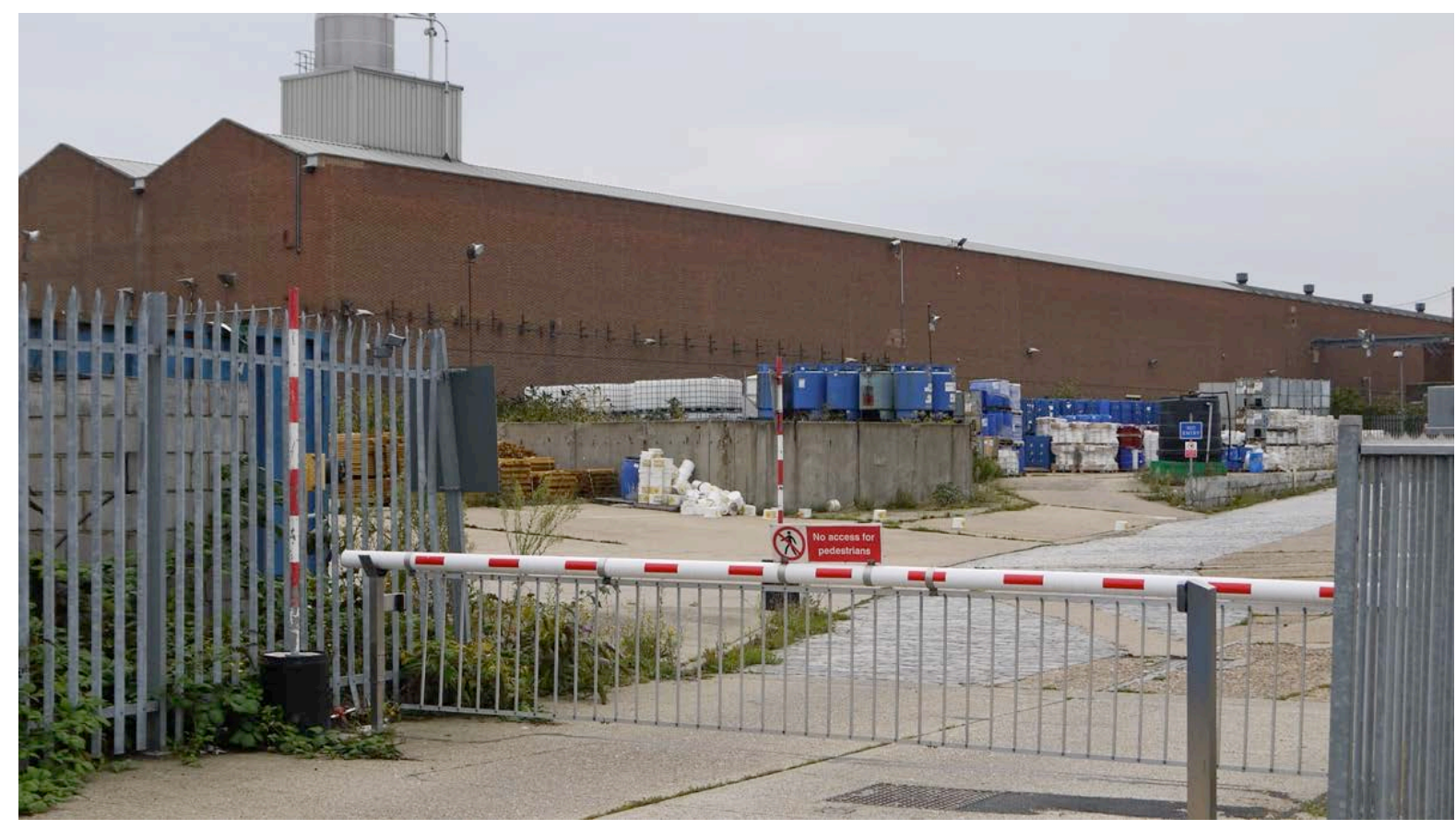

Figure 14. Brenntag Chemicals, Morden Wharf. 


\section{Game 4: Victoria Deep Water Terminal}

S. What are we doing here?

G. When?

S. Isn't it tomorrow?

G. Isn't what tomorrow?

S. Aren't we here for a reason?

G. What reason is that?

S. Where are we going?

G. Where would you like to go?

S. How long will it take?

G. How long have you got?

S. What time do we start?

G. What time will you arrive?

S. How many people will be there?

G. How many will turn up?

S. What will I have to do?

G. What would you like to do?

S. Would I have to read?

G. Would you like to read?

S. What can I read?

G. What would you like to read?

S. Can anyone come?

G. Do you have to ask?

S. Would you like to answer?

G. If you would like to be part of tomorrow's geopoetry walk around the Greenwich Peninsula, we have provided a map of the route we will be taking, the texts that will form the basis of the reading, the sites where we will largely read them, and the approximate time we will be there. That should allow you to find us and join in. Whether you wish to come to a single reading or the whole walk is up to you. You may turn up and chose to read a text; you may listen to one that's being read; or you may bring your own text along and read it at some point on the journeys between locations. However, since a geopoetry walk is as much about the journey between the places as the readings themselves, we strongly suggest that you come to more than one location, whether as reader or listener, speaker or walker, audience or performer.

\section{S. Statement: 2-all. Match point.}




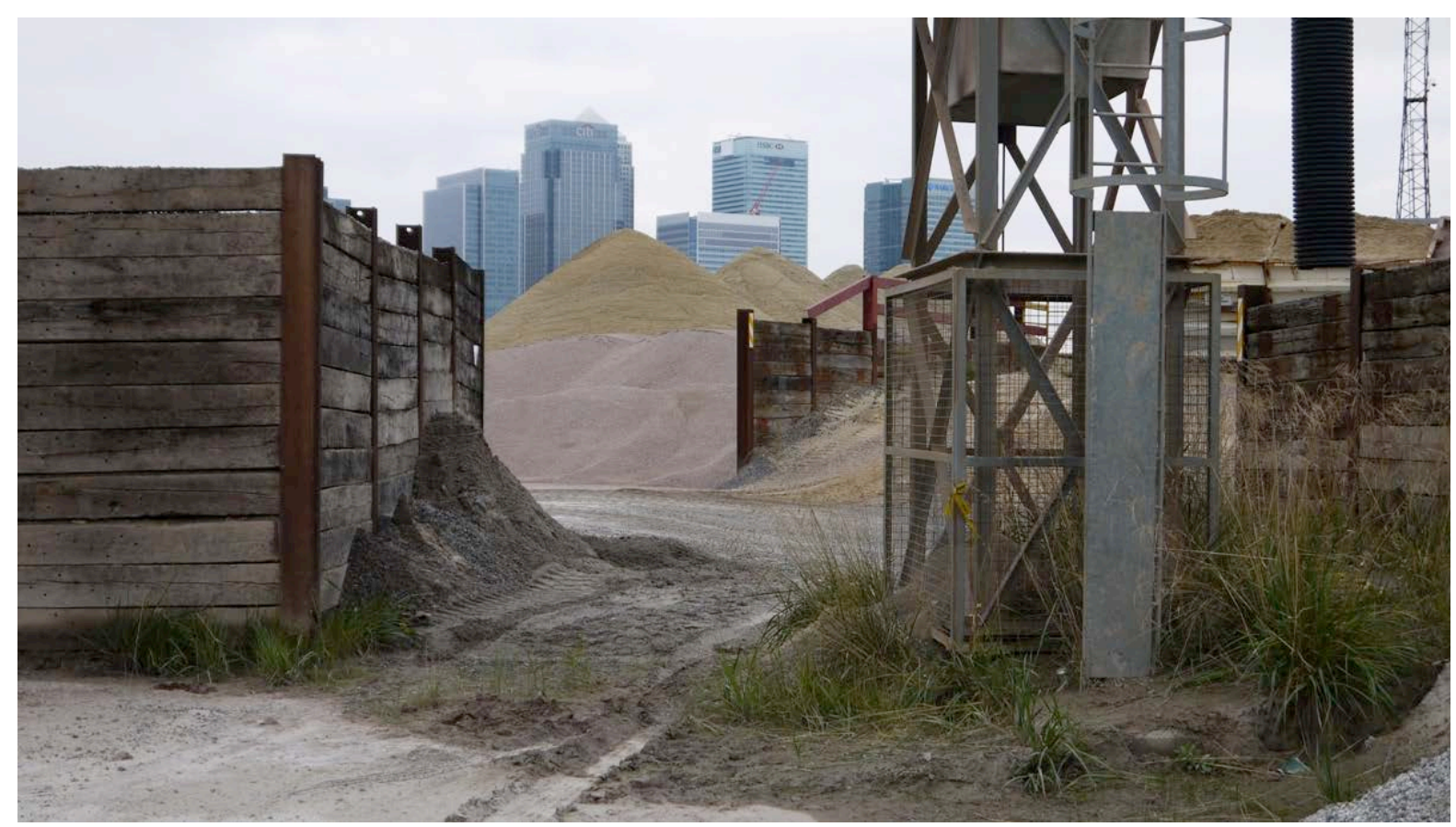

Figure 15. Victoria Deep Water Terminal. 


\section{Game 5: Blackwall Tunnel}
S. Is that our final answer?
G. Who's answering?
S. And we won't answer any more questions?
G. Haven't we established that?
S. Then we have nothing more to say?
G. Is that what we said?
S. Do you know what Guy Debord said?
G. Who?
S. Were you there in September 1960?
G. When?
S. Have you heard of the ICA meeting?
G. Where?
S. 'We're not here to answer cuntish questions!'

G. Statement: 3-2. Game, Set and Match. 


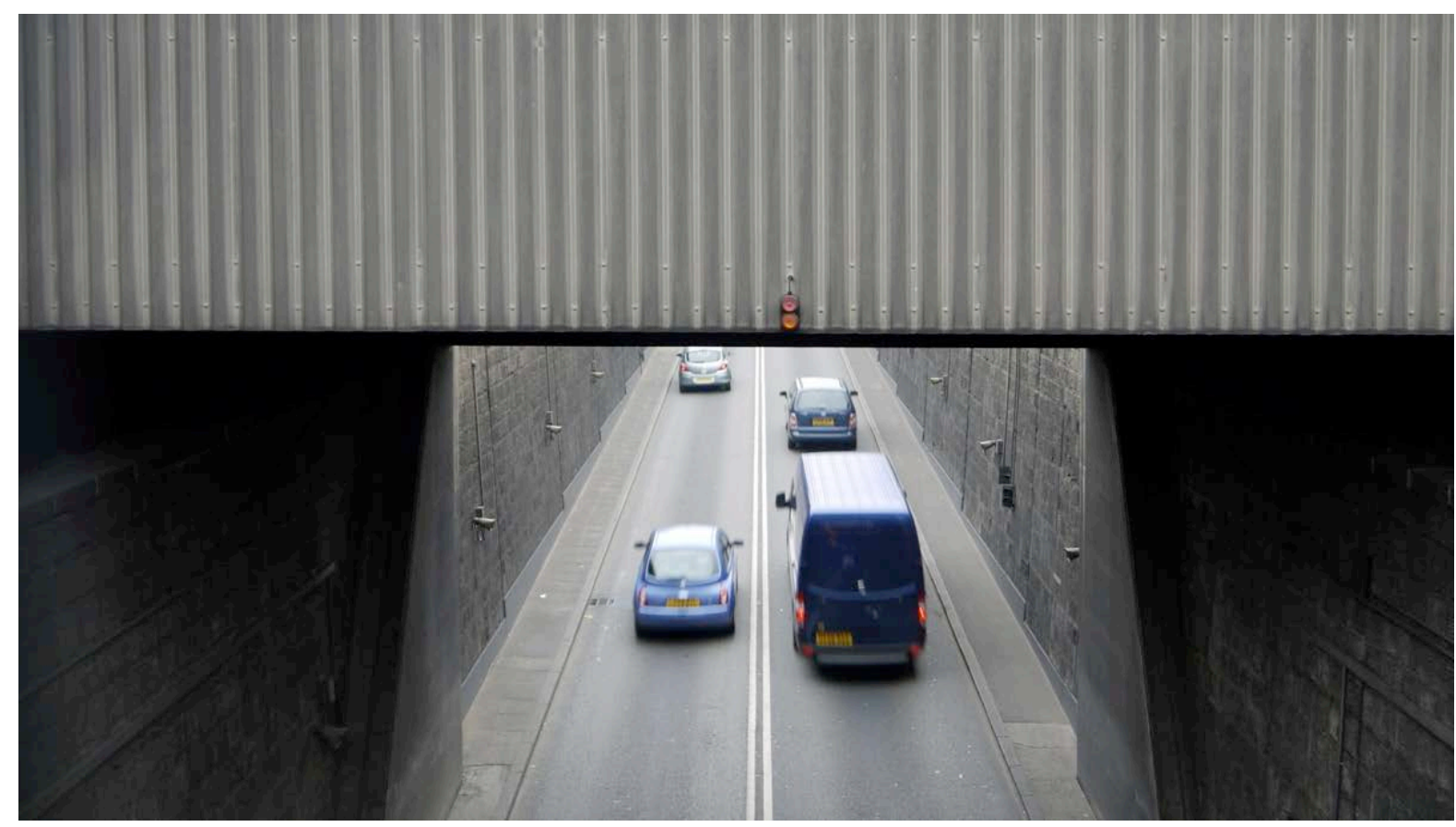

Figure 16. Blackwall Tunnel, south exit. 